\title{
An auspicious victory
}

\section{A vote by the US House of Representatives to ease restrictions on embryonic stem-cell research marks an important tuming point - whether President Bush vetoes the change or not.}

ast week, the US House of Representatives voted by 238 to 194

to reverse the policy restricting embryonic stem-cell research that was implemented by President George W. Bush back in 2001 (see page 544).

The measure will now be taken up by the Senate, where it has a good chance of success. However, Bush said both before and after the House vote that he will veto the measure if it reaches his desk. Even that won't erase the significance of this first victory in the Republican-controlled House for advocates of stem-cell research. The fact that 50 Republican members voted for the change in policy underlines the fact that the pendulum of public opinion is swinging strongly in favour of allowing more of the research to go ahead.

That augers well for the eventual loosening of federal policies that have kept scientists' hands tied in the United States. Some influential Republicans - including Nancy Reagan, the wife of a former president, and conservative Utah senator Orin Hatch - have spoken out in favour of embryonic stem-cell research, making it easier for others to publicly support the work as well.

Indeed, the desperate language used by opponents of embryonic stem-cell research suggests they know they are losing the debate. Tom DeLay (Republican, Texas), majority leader in the House, said on Tuesday last week that a vote for the stem-cell bill was a vote "to fund with taxpayer dollars the dismemberment of living distinct human beings for the purposes of medical experimentation".

There's no indication that the public is buying this. Polling evidence suggests that most Americans instead have high hopes for the research, and biomedical advocacy groups have done an effective job convincing lawmakers that the research deserves a chance to fulfil these hopes. Years of tireless lobbying by these groups played a major role in the 24 May victory. So too did competitive pressure from overseas, with South Korean research making headline news just ahead of the vote, and from state governments, whose own initiatives in this sphere are forging ahead in California, New Jersey and elsewhere.

Even if the measure passed by the House becomes law, the United States would retain more restrictions on publicly funded research than do nations such as South Korea and Britain, both of which allow publicly supported scientists to use somatic cell nuclear transfer to derive fresh embryonic stem-cell lines. The US measure would allow federal funding only for work on embryos left over from in vitro fertilization clinics.

In the Senate, Sam Brownback (Republican, Kansas) has already said that he will attempt to block a vote on the stem-cell measure, so that for the measure to pass it will need the support of 60 out of the 100 senators. If it obtains these votes, the bill will arrive on President Bush's desk - and he'll face a difficult choice.

The proponents of stem-cell "The desperate language used by opponents of embryonic stem-cell research suggests they know they are losing the debate." research have mooted the idea of some sort of compromise, which might, for example, update the 2001 policy to allow publidy funded work on more recently derived stem cells. But the president has chosen to draw what he sees as a moral line in the sand that he feels he cannot cross. He has threatened to make this the first bill that he has vetoed in four-and-a-half years in office. But the veto, if it is used, will place him squarely against public opinion in the United States, which increasingly views embryonic stem-cell research not with fear, but with hope.

\section{Seeds in threatened soil}

US hostility towards Syria is undermining the stability of an important seed bank for dry areas.

\rceil hirty kilometres from Aleppo in Syria, not far from the birthplace of agriculture, is the International Center for Agricultural Research in the Dry Areas (ICARDA). It includes an international gene bank that holds seeds in trust on behalf of the world's dry countries.

Organized through the World Bank and funded by international donors, ICARDA's gene bank holds samples of 131,000 individual seeds for plants that form part of the diets of one billion people who live in Central and West Asia, the Middle East and North Africa. The seeds include different varieties of barley, beans, chickpeas and lentils, catalogued and stored in sealed plastic bottles inside giant refrigerated vaults.

ICARDA often finds itself having to rebuild agriculture at the end of military and civil conflicts. The centre is in effect a lender of last resort for farmers and scientists who have nowhere else to go when their seeds run out.

When Taliban fighters looted Afghanistan's national seed store in 2002, they took the empty plastic bottles, leaving the seeds behind. Even so, the country's scientists needed ICARDA's help to rebuild the store. And shortly before the US invasion of Iraq in March 2003, Iraqi scientists sent a 'black box' across the border to ICARDA containing copies of the country's seed stocks. The action was timely, as Iraq's seed bank, in the Baghdad suburb of Abu Ghraib, was looted and destroyed during the insurgency. ICARDA plans to use the contents of the box to help regenerate Iraqi farming.

But now the centre's host country is itself feeling the heat of US 
rhetoric. The US government has always been a generous financial supporter of the centre's activities. But in the words of the State Department, Syria is autocratic, is a state sponsor of terrorism, and is believed to be developing weapons of mass destruction. Continuing US sanctions and some discussion in the United States about

"\$260 million is a relatively small price to pay to conserve the world's food heritage and secure the future supply of food for the world." possible 'regime change' are causing nervousness.

One response would be to pack the seeds into storage boxes and airlift them out of Syria, but the threat of US military action currently seems too remote to warrant such drastic action.

Much better, for ICARDA and for the 14 other 'Future Harvest Centres', would be for more support to be given to the Global Crop Diversity Trust, an international fund to build more gene banks around the world and to improve the conditions of existing ones. The trust was set up jointly by the United Nations' Food and Agriculture Organization (FAO) and the Consultative Group on International Agricultural Research. It says it needs an endowment of $\$ 260$ million to safeguard seeds used in world agriculture and to improve the condition of the gene banks where they are stored.
The world's gene banks are in a parlous state, as a new report ( (Safeguarding the future of US agriculture") published jointly by the US Department of Agriculture and the University of California makes clear. Of the 1,460 gene banks around the world, only 35 meet international standards for long-term storage. These include the gene banks of ICARDA and of the other Future Harvest Centres. The FAO, moreover, says that nearly-one fifth of the 5.4 million seeds stored in gene banks are degenerating.

The US report also urges the Bush administration to support the Global Crop Diversity Trust, and not without good reason. Pests and plant diseases are causing losses to US agriculture of up to $\$ 33$ billion each year, and there is a strong fear that new threats could cause even more damage. US agricultural researchers are currently scouring the world's gene banks for seed varieties that can resist these diseases. Chief among such diseases are a fungus that is currently invading US soybean fields, and potato blight of the kind that caused the Irish potato famine, which is destroying potatoes worth some $\$ 400$ million each year.

The US government is currently spending more than $\$ 1$ billion per week on military operations in Iraq. By comparison, a $\$ 260$ million endowment is a small price to pay to conserve the world's agricultural heritage and to secure the future food supply of the United States and the rest of the world.

\section{Too much, too soon}

\section{How not to promote your latest research findings in the media.}

$\wedge$ tour de force; an impressive advance; years ahead of its time. When South Korean researchers declared last month that that they had created stem-cell lines genetically matched to individual patients, commentators were ready with superlatives, and rightly so. The paper (W. S. Hwang et al. Science doi:10.1126/ science.1112286;2005) is a major step towards the use of stem cells in the study and treatment of disease.

In Britain, however, many usually well-informed members of the public may be labouring under the illusion that it is their nation, and not South Korea, that is pushing back the boundaries of stem-cell research. For just as Hwang's paper appeared in press, a second one - or, at least, an abstract of one - sprang forth from a team of biologists at the University of Newcastle upon Tyne. This group, led by fertility specialist Alison Murdoch, had not matched Hwang's achievements - they merely described the creation of a cloned embryo, not the extraction of cell lines - but they stole most of his thunder in the UK press.

If this were just a routine case of domestic media favouring local achievements, it wouldn't matter much. But the manner in which the Newcastle team made its discovery public has consequences that reach beyond one day's headlines. As researchers in the field have been angrily informing Nature since the two pieces of work appeared, the approach taken in this case risks damaging science and its public perception.

The Newcastle team submitted its work to an independent Cam- bridge-based journal, Reproductive BioMedicine Online, which has the unusual policy of making abstracts of submitted papers available on its website as soon as the articles are sent out for peer review. The full paper is kept confidential until it is accepted and published. So science reporters informed of the findings by a telephone briefing had access to an abstract that had not been peer reviewed - and to nothing else.

It can't yet be determined for certain if the Newcastle team was intending to ride the wave of publicity for the South Korean paper, or if it simply submitted its paper to the journal at a fortuitous moment. And in an ideal world, science reporters would know the difference between a significant breakthrough and a local, incremental result.

But the premature release of this incomplete information, without any form of peer review and without making it clear to journalists that the work had not been refereed, is contrary to good scientific practice. The paper could, in principle, be revised or "The premature release of
incomplete information,
without peer review and
without making it clear
to journalists that it
has not been refereed,
is contrary to good
scientific practice." even rejected after peer review, in which case the public would have been misinformed. The absence of a paper also prevents other researchers from assessing or responding to the Newcastle results.

Industrial companies already release claims to the media while keeping data confidential for commercial reasons, and that's frustrating enough. The last thing the science community needs is for publicly funded academic researchers to start playing the same game. And to do so in the technically and ethically contentious arena of stem cells is playing with fire. 